\title{
Legal Framework for Development of Micro, Small and Medium Enterprises by Local Governments as an Effort for Economic Recovery
}

\author{
Martha Riananda \\ Constitutional Law \\ Lampung University \\ Lampung, Indonesia \\ marthamahdi@gmail.com
}

\author{
Malicia Evendia \\ Constitutional Law \\ Lampung University \\ Lampung, Indonesia \\ 0000-0003-0794-3135
}

\author{
Ade Arif Firmansyah* \\ Constitutional Law \\ Lampung University \\ Lampung, Indonesia \\ ade.firmansyah@fh.unila.ac.id
}

\begin{abstract}
The existence of Micro, Small, and Medium Enterprises has a strategic role in advancing the national economy. This can be seen from the contribution of MSMEs in absorbing a very large workforce. MSMEs are believed to be the leading sector in the economy in Indonesia and become an integral part of the people's economy. This study aims to analyze the legal framework that local governments can do in developing MSMEs as one of the current economic recovery efforts. The Covid19 pandemic, which has had a major impact on the economy, requires the government, including regional governments, to issue various policies in the context of accelerating economic recovery. This study uses a normative legal research method with a statutory and conceptual approach. The results of this study indicate that: the issuance of Law Number 11 of 2020 concerning Job Creation as a form of legal policy by the central government, has legal implications that become a way for local governments to determine the direction of legal policy for the development of MSMEs. The legal framework for developing MSMEs by local governments is through the establishment of Regional Regulations on the Ease, Protection, and Empowerment of Micro, Small, and Medium Enterprises. This regional regulation becomes the legal framework for local governments to optimize the development of MSMEs based on regional authority. The formation of these regional regulations is a legal requirement in response to legal developments that have changed with the issuance of Government Regulation Number 7 of 2021 as a derivative rule of Law Number 11 of 2020 concerning Job Creation.
\end{abstract}

Keywords - micro, small and medium enterprises; local government; economic recovery

\section{INTRODUCTION}

One of the important aspects of development is the right to work and a decent living [1]. The 1945
Constitution of the Republic of Indonesia has mandated that the purpose of the establishment of the Republic of Indonesia is to create a prosperous, just, prosperous, equitable society, both spiritually and materially. Every citizen has the right to work and a decent living for humanity. Article 27 paragraph (2) of the 1945 Constitution stipulates that the state needs to make various efforts or actions to fulfill this right. And a decent life.

A society based on justice and prosperity and a constitution dating to 1945 must be developed through economic democracy. This is in line with the mandate of the Decree of the People's Consultative Assembly of the Republic of Indonesia Number XVI/MPR-RI/1998 concerning Economic Politics in the context of Economic Democracy, that Micro, Small, and Medium Enterprises, which are an integral part of the people's economy, that have strategic positions, roles, and potentials need to be empowered to realize a balanced, developing, and just national economic structure.

Small, medium and micro businesses contribute to economic growth through employment opportunities, equity, and income. In addition, small and mediumsized businesses are one of the main pillars of the national economy, which should receive basic opportunities, support, protection, and development to the maximum extent possible as a form of aligning enterprises with economic groups of people, while not ignoring the role of large businesses and economic entities with state participation [2]. The government in empowering and developing MSMEs has issued policies through laws and regulations, including Law Number 20 of 2008 concerning Micro, Small, and Medium Enterprises. This arrangement is basically to empower micro, small and medium enterprises. 
The Regional Government in terms of empowerment and development of MSMEs also takes part and is responsible for this, apart from being regulated in the laws and regulations governing MSMEs, it has also been regulated in Law Number 23 of 2014 concerning Regional Government as amended the last time by Law No. Law Number 9 of 2015 concerning the Second Amendment to Law Number 23 of 2014 concerning Regional Government.

MSMEs as the leading sector in the Indonesian economy, have contributed greatly to gross domestic product (GDP). The MSME sector contributed at least Rp8,573.9 trillion (57.8 percent) to Indonesia's GDP which in 2018 reached Rp14,838.3 trillion. MSMEs now employs around 117 million (97 percent) of the total Indonesian workforce, and present 64 million business units, or $99.99 \%$ of the total business units in Indonesia [3]. But unfortunately, the large contribution of MSMEs to the economy has not been accompanied by maximum attention to the development of MSMEs. Several classic problems are still a problem that entangles MSMEs. MSMEs still face various obstacles and constraints, both internal and external. These issues include capital, licensing, marketing, human resources, databases, business climate, and access to government projects.

Especially when we are faced with the Corona Virus Disease pandemic. Coronavirus disease or commonly known as COVID 19 is one of the new viruses discovered in December 2019. It is known that this virus was first discovered in Wuhan, China. In March 2020, this virus began to enter Indonesia with various harmful effects on human health, so the Indonesian government acted decisively in fighting the quo virus. The existence of this pandemic, apparently not only has an impact on public health but also has an impact on the community's economy, including MSME business actors.

As an effort to overcome various problems and to encourage the development of MSMEs, the government has established Law Number 11 of 2020 concerning Job Creation (Job Creation Law). This law is an omnibus law that contains various clusters. The enactment of the law has changed several legal substances contained in the patent law. One of the clusters regulated in the law is regarding MSMEs.

After the enactment of the Job Creation Law, the Government, Regional Government, the Business World, and the community as a whole, synergistically and sustainably, need to make efforts to increase the capacity and role of Micro, Small, and Medium Enterprises institutions in the national economy. Current developments, especially with the enactment of the Job Creation Law, and the impact of the pandemic on the economy, local governments need to respond to the demands and needs in developing MSMEs. Based on the background described above, the formulation of the problem that will be answered in this paper is: what is the Legal Framework for the Development of SMEs by the Regional Government as an effort to recover the economy?

\section{RESEARCH METHODS}

This research examined various laws and regulations that are used as the basis for legal provisions to analyze the legal framework for developing MSMEs by local governments. The legal research model used is a study that includes primary legal materials as well as secondary materials. This research examines the statutes and cases that are related to the concepts of the research [4]. The research into a systematic explanation was conducted to obtain a clear picture of the problem under study and the conclusion of the data analysis.

\section{Discussions AND ANALYSIS OF RESUlTS}

To understand and answer the research problems, the following will be presented in the following subchapters description and analysis.

\section{A. The Role and Position of MSMEs in the Economy in Indonesia}

Business is an economic unit that carries out activities to produce goods/services to be sold or exchanged for other goods and there are one or more persons who are responsible and have the authority to manage the business. The position of small businesses in the Indonesian economy has become increasingly important, especially after the crisis hit Indonesia.

The crisis has proven that MSMEs are more resilient than most large businesses. In addition, equity will be more effective through the development of small businesses because of their large numbers and generally labor-intensive nature [5]. Small and microbusinesses have a strategic value in strengthening the economy. The government should give attention to strategies and policies designed to empower groups of people in the business world. This will increase the cost of living and its competitiveness. The need for the goods and services sector of the economy to be given more careful attention by various aspects of society is the forerunner of entrepreneurship in the process [6].

The people's economy, which has strong resilience or resilience in the current situation, must be used as a mainstay to recover the Indonesian economy from crisis conditions. According to Mubyarto, "because of the important role the Ekonomi Rakyat (estimated about $50-60 \%$ of total Indonesian economy), the economic recovery has taken place, and the people's economy has adjusted to the changing situation relatively easily" [7]. In Indonesia, the role (sector) of the people's economy, which is flexible and resilient, is very large (around $55 \%$ ) so that in reality the people's economic sector can easily adapt to changing socio-political-security conditions [6].

MSME is a form of people's economic system. The people's economy that Zulkarnain said is an economic 
system that must be adhered to following our philosophy. It involves justice and economic democracy, as well as standing on the side of the people's economy. [8]. An understanding of the people's economy can be viewed from two approaches [9], namely by looking at how economic activity takes place among people in small-scale economic activities. The focus of this paper is on the empowerment of smallscale economic actors. Second, the economic system approach, in which the people are in control of the economy, is called participatory development. Based on this second approach, the economic empowerment of the people is intended to apply the principles of democracy in development based on its principles. Society is the driving force of development and people are involved in the process from all levels. And this second approach is often referred to as an economy or a national economic system. Suharto Prawiro Kusumo, a proponent of economic democracy, put forward some of the characteristics and principles in the concept of people's economy. The characteristics are as follows [10]:

- The main characteristic of a democratic economic system or a people's economy is that it is governed by the principle of justice, which is accompanied by concern for the weak. The economy should allow each individual to be a consumer, an entrepreneur, or a worker.

- In line with the principle of the first nature and the characteristics of partiality, empowerment, and protection of the weak by the nation's government, especially its capabilities. The government does this through economic measures.

- Encouraging fair business competition and market-friendly interventions. Efforts to equalize go hand in hand with efforts to create a competitive market to achieve optimal efficiency. Businesses of all sizes must be based on capability, not compassion.

- Efforts to move the rural economy are closely related to the empowerment of people's economic activities. Therefore, efforts to accelerate rural development, minus areas and critical areas, must be a priority.

- Some of the resources that are most vital to human survival are land and other natural resources. All must be managed fairly, transparently, and productively to prioritize the rights of the local people, including the customary rights of indigenous peoples.

Meanwhile, according to Mubyarto, efforts to develop the people's economy can be seen from three sides, namely: First, creating an atmosphere or climate that allows the potential of the community to develop. The assumption is that every human being and the human group has potential that can be developed. No society is completely powerless. Second, strengthening the economic potential of the community. The very main efforts are increasing the level of education, enlightenment or (Aufklarung), increasing health status, and opening up opportunities to take advantage of economic opportunities. Third, protect the people and prevent unequal competition, as well as prevent the exploitation of the strong economic group over the weak [11].

Thus, the role and position of MSMEs occupy an important position in the Indonesian economy. MSMEs in addition to having a large contribution to Gross Domestic Product, MSMEs that are labor-intensive are also able to absorb a wide workforce. MSMEs are a form of people's economy as a character of the economy in Indonesia.

\section{B. MSME Development and Implications of the Job Creation Act}

Normatively, the definition of Development in Law Number 20 of 2008 is an effort made by the Government, Regional Government, Business World, and the community to empower Micro, Small, and Medium Enterprises through the provision of facilities, guidance, assistance, and reinforcement assistance to grow and improve their capabilities. The competition levels of Micro, Small, and Medium Enterprises. Article 3 of the regulation in this law stipulates that Micro, Small, and Medium Enterprises aim to grow and develop their business in the context of building a national economy based on just economic democracy.

The presence of the Job Creation Law brings with it many legal implications. Many laws and regulations have been amended and even revoked with the issuance of this Job Creation Law. The Job Creation Law has been implemented to support job creation. It is necessary to adjust various aspects of the law to do so, including improving the investment ecosystem and accelerating national strategic projects. Therefore, through the Job Creation Law, there is a change in the content of the content contained in Law Number 20 of 2008 and Government Regulation Number 17 of 2013 concerning the Implementation of Law Number 20 of 2008 concerning Micro, Small, and Medium Enterprises which are now no longer valid.

Job creation is an effort to create jobs through facilitating, protecting, and empowering cooperatives and micro, small and medium enterprises, improving the investment ecosystem and facilitating business, and investing in the Central Government, and accelerating national strategic projects. Article 3, the Job Creation Act was established with the aim of:

- Create and increase job opportunities by providing convenience, protection, and empowerment for cooperatives and MSMEs, as well as national industry and trade, to make sure that the widest possible Indonesian workforce 
can be absorbed while taking into account the balance and progress between regions;

- ensure that every citizen gets a job and fair and appropriate remuneration and treatment in an employment relationship;

- make adjustments to various aspects of regulation relating to alignments, strengthening, and protection for cooperatives and MSMEs as well as national industry; and

- The president proposed to make adjustments to various regulatory aspects related to improving the investment ecosystem, facilitating and accelerating national strategic projects oriented to national interests based on national science and technology guided by Pancasila.

To achieve this goal, the Job Creation Law regulates various strategic job creation policies which include:

improvement of the investment ecosystem and business activities;

- employment;

- convenience, protection, and empowerment of cooperatives and MSMEs;

- ease of doing business;

- research and innovation support;

- land acquisition;

- economic area;

- Central Government investment and acceleration of national strategic projects;

- implementation of government administration; and

- imposition of sanctions

MSMEs are one of the sectors that greatly impact the existing policies in the Job Creation Act. Various facilities have been regulated to ensure legal certainty, the ecosystem to be achieved by the central government provides wide opportunities in the development of MSMEs. With the existence of MSMEs with the issuance of the Job Creation Law, it is hoped that they can go up in class and can develop and be competitive. The increasingly strong economic liberalization needs to be balanced with strengthening and protection for MSMEs, which are miniatures of the economic system in Indonesia.

\section{Legal Framework for MSME Development by} Local Governments in Economic Recovery Efforts

Efforts to develop MSMEs through legal functions are necessary. Considering that the State of Indonesia is the State of Law as regulated in Article 1 paragraph (3) of the 1945 Constitution. Consequently, all government actions in the administration of the state must be based on law.

The development of MSMEs is not only the responsibility of the central government. Local governments through the division of concurrent affairs as regulated in Law Number 23 of 2014, have the authority and obligation to develop MSMEs. One of the mandatory government affairs that are not related to basic services as regulated in Article 12 paragraph 2 is the field of cooperatives, small and medium enterprises.

The role of local governments is needed to improve the development of MSMEs in business competition and economic globalization which is increasingly stringent, this is the responsibility of local governments that needs to be implemented based on regional autonomy. Regional Autonomy has a huge impact on local government. This is because, with the enactment of the regional government law, regional governments have full authority in carrying out development in their respective regions [12]. As stated by Hoessein, regional autonomy is the authority to regulate local government affairs according to their initiatives based on people's aspirations [13]. In detail, the local government's authority over MSMEs according to Law Number 23 of 2014 concerning Regional Government is presented in the following table.

TABLE I. PROVINCIAL AND REGENCY/MUNICIPAL GOVERNMENT AUTHORITIES REGARDING MSMES ACCORDING TO LAW NUMBER 23 OF 2014

\begin{tabular}{|c|c|c|}
\hline Sub Affairs & $\begin{array}{c}\text { Provincial } \\
\text { Government } \\
\text { Affairs } \\
\end{array}$ & $\begin{array}{c}\text { District/City } \\
\text { Government Affairs }\end{array}$ \\
\hline $\begin{array}{l}\text { MSME } \\
\text { Empowerment } \\
\text { Sub-business }\end{array}$ & $\begin{array}{l}\text { Empowerment of } \\
\text { small businesses } \\
\text { is carried out } \\
\text { through data } \\
\text { collection, } \\
\text { partnerships, ease } \\
\text { of licensing, } \\
\text { institutional } \\
\text { strengthening, } \\
\text { and coordination } \\
\text { with stakeholders. }\end{array}$ & $\begin{array}{l}\text { Empowerment of } \\
\text { micro-enterprises is } \\
\text { carried out through } \\
\text { data collection, } \\
\text { partnerships, ease of } \\
\text { licensing, institutional } \\
\text { strengthening, and } \\
\text { coordination with } \\
\text { stakeholders. }\end{array}$ \\
\hline $\begin{array}{l}\text { MSME } \\
\text { Development } \\
\text { Sub-business }\end{array}$ & $\begin{array}{l}\text { Development of } \\
\text { small businesses } \\
\text { with the } \\
\text { orientation of } \\
\text { increasing the } \\
\text { scale of business } \\
\text { into medium } \\
\text { enterprises. }\end{array}$ & $\begin{array}{l}\text { Development of } \\
\text { micro-enterprises } \\
\text { with the orientation of } \\
\text { increasing the scale of } \\
\text { business into small } \\
\text { businesses. }\end{array}$ \\
\hline
\end{tabular}

Furthermore, the regulation of MSMEs is also regulated in Law Number 20 of 2008 concerning Micro, Small, and Medium Enterprises. The following are some of the provisions in Law Number 20 of 2008 concerning Micro, Small and Medium Enterprises related to the authority of the Regional Government.

Article 7 paragraph (1) of Law Number 20 of 2008 contains provisions that the Government and Regional Governments develop a Business Climate by 
stipulating laws and regulations and policies covering aspects of:

- funding;

- facilities and infrastructure;

- business information;

- partnership;

- business license;

- business opportunities;

- trade promotion; and

- institutional support.

Furthermore, in Article 7 paragraph (2), the Business World and the community actively participate in helping to grow the Business Climate. These aspects in Law No. 20 of 2008 have been elaborated in subsequent articles.

In addition to these aspects, Article 16 paragraph (1) stipulates that the Government and Regional Governments facilitate business development in the fields of production and processing; marketing; Human Resources; and design and technology. The role of the business world and the community in the development process is notable. Concerning funding sources, Article 23 Paragraph (1) of Law No. 20 of 2008 states that to increase the access of small and micro enterprises to funding sources for the government and regional governments: a.) grow, develop and expand networks of non-bank financial institutions; b.) Strengthening the position of credit guarantee institutions; and providing convenience and facilitation in fulfilling the requirements to obtain financing. Meanwhile, businesses and the community are actively participating in improving micro and small business access to credit or credit by a.) Improve the ability to prepare commercial feasibility studies; b.) increasing knowledge about procedures for applying for credit or loans, and also improving technical and managerial understanding and skills of the business.
In addition to these laws and regulations, which are the basis for the authority of local governments in developing MSMEs. The enactment of Law Number 11 of 2020 concerning Job Creation is also the basis for the authority of local governments in developing MSMEs.

The pandemic, which has had a major impact on the economy, requires the government, including local governments, to issue various policies to accelerate economic recovery. This is reinforced by the issuance of Law Number 11 of 2020 concerning Job Creation, as the legal basis for local governments to issue legal policies in the development of MSMEs. The development of small businesses is currently a priority in driving the national economy, considering that its business activities cover almost all business fields so that the contribution of small businesses is very large for increasing income for low-income groups.

Employment creation carried out through arrangements related to the convenience, empowerment, and protection of MSMEs shall at least contain arrangements regarding: ease of establishment, member meetings, and cooperative business activities, and MSME criteria, a single MSME database, integrated management of MSMEs, ease of MSME Business Licensing. , partnerships, incentives, and MSME financing. As for in detail the provisions governing the convenience, protection, and empowerment of cooperatives and MSMEs are regulated in Chapter V of the Job Creation Law.

As regulated in Article 85 of Law Number 11 of 2020 , that to provide convenience, protection, and empowerment of MSMEs, this Law amends, deletes, or stipulates new arrangements for several provisions stipulated in Law Number 20 of 2008 concerning Micro Enterprises, Small, and Medium. Based on Article 87, the following are presented some of the provisions in Law Number 20 of 2008 which have been amended, by juxtaposing them with the provisions before they were amended.

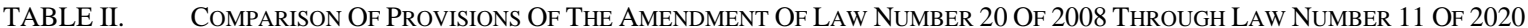

\begin{tabular}{|c|c|c|}
\hline Provision & After Change & Before Change \\
\hline Article 6 & $\begin{array}{l}\text { Micro, Small, and Medium Enterprises may qualify for } \\
\text { special consideration based on business capital, } \\
\text { turnover, net worth, annual sales, investment value, } \\
\text { incentives and disincentives, application of } \\
\text { environmentally friendly technology, local content, or } \\
\text { the number of workers. } \\
\text { The criteria for Micro, Small, and Medium Enterprises } \\
\text { shall be regulated in a Government Regulation. }\end{array}$ & $\begin{array}{l}\text { Criteria for Micro Enterprises are as follows: a. has a net worth of } \\
\text { at most Rp. } 50,000,000.00 \text { (fifty million rupiahs) excluding land } \\
\text { and buildings for business premises; or b. have annual sales of a } \\
\text { maximum of Rp. } 300,000,000.00 \text { (three hundred million rupiahs). } \\
\text { Small Business Criteria are as follows: a. has a net worth of more } \\
\text { than Rp. } 50,000,000.00 \text { (fifty million rupiahs) up to a maximum } \\
\text { of Rp. } 500,000,000.00 \text { (five hundred million rupiahs) excluding } \\
\text { land and building for business; or b. have annual sales of more } \\
\text { than Rp. } 300,000,000.00 \text { (three hundred million rupiahs) up to a } \\
\text { maximum of Rp.2,500,000,000.00 (two billion five hundred } \\
\text { million rupiahs). } \\
\text { The criteria for Medium Enterprises are as follows: a. has a net } \\
\text { worth of more than Rp. } 500,000,000.00 \text { (five hundred million } \\
\text { rupiahs) up to a maximum of Rp. } 10,000,000.00 \text { (ten billion }\end{array}$ \\
\hline
\end{tabular}




\begin{tabular}{|c|c|c|}
\hline & & $\begin{array}{l}\text { rupiahs) excluding land and building for business; or b. have } \\
\text { annual sales of more than Rp. } 2,500,000,000.00 \text { (two billion five } \\
\text { hundred million rupiahs up to a maximum of } \\
\text { Rp. } 50,000,000,000.00 \text { (fifty billion rupiahs). }\end{array}$ \\
\hline Article 12 & $\begin{array}{l}\text { Aspects of business licensing as referred to in Article } 7 \\
\text { paragraph (1) letter e are aimed at: a. simplify the } \\
\text { procedures and types of Business Licensing with a one- } \\
\text { stop integrated service system and b. waive Business } \\
\text { Licensing fees for Micro Enterprises and provide relief } \\
\text { from Business Licensing fees for Small Businesses. } \\
\text { Further provisions regarding the requirements and } \\
\text { procedures for Licensing, Undertaking shall be } \\
\text { regulated in a Government Regulation. }\end{array}$ & $\begin{array}{l}\text { Aspects of business licensing as referred to in Article } 7 \text { paragraph } \\
\text { (1) letter e are aimed at: a. simplify procedures and types of } \\
\text { business licensing with a one-stop integrated service system, and } \\
\text { b. waive licensing fees for Micro Enterprises and provide relief } \\
\text { from licensing fees for Small Businesses. } \\
\text { Further provisions regarding the requirements and procedures for } \\
\text { applying for a business license shall be regulated by a } \\
\text { Government Regulation. }\end{array}$ \\
\hline Article 21 & $\begin{array}{l}\text { The central and regional governments provide } \\
\text { financing to small and micro-enterprises. } \\
\text { State-Owned Enterprises provide financing from the } \\
\text { profit share allocated to Micro and Small Enterprises in } \\
\text { the form of loans, guarantees, grants, and other kinds } \\
\text { of financing. } \\
\text { Large corporations in the United States, both domestic } \\
\text { and foreign, should provide loans, grants, and } \\
\text { guarantees to small and medium-sized enterprises. } \\
\text { The central government, regional governments, and the } \\
\text { business world will provide grants, seek foreign aid, } \\
\text { and seek other sources of financing that are not legally } \\
\text { binding for small and micro-enterprises. } \\
\text { The Central Government and Regional Governments } \\
\text { following their authority shall provide incentives in the } \\
\text { form of ease of licensing requirements, reduced tariffs } \\
\text { for facilities and infrastructure, and other forms of } \\
\text { incentives to the Business World that provides } \\
\text { financing for Micro and Small Enterprises. }\end{array}$ & $\begin{array}{l}\text { The government and regional governments provide financing for } \\
\text { micro and small businesses. } \\
\text { State-owned enterprises may provide financing in the form of } \\
\text { loans, grants, and other forms of financing for micro-and small- } \\
\text { sized enterprises. } \\
\text { National and foreign large companies often provide loans, } \\
\text { guarantees, grants, and other types of financing to small and } \\
\text { micro-enterprises. } \\
\text { The Government, Regional Government, and the Business World } \\
\text { have several different ways that they can provide grants, seek } \\
\text { foreign aid, and seek other sources of financing for Micro and } \\
\text { Small Enterprises. } \\
\text { he Government and Regional Governments can provide } \\
\text { incentives in the form of ease of licensing requirements, reduction } \\
\text { of tariffs for facilities and infrastructure, and other forms of } \\
\text { incentives for businesses that provide financing for Micro and } \\
\text { Small Enterprises. }\end{array}$ \\
\hline Article 25 & Removed & $\begin{array}{l}\text { The government, regional government, business world, and the } \\
\text { community encourage, support, and benefit from partnerships, } \\
\text { which are based on mutual need, trust, and strength. } \\
\text { Partnerships between micro, SMEs, and micro, SMEs, and large } \\
\text { enterprises cover the process of skill transfer in the areas of } \\
\text { production and processing, marketing, capital, human resources, } \\
\text { and technology. } \\
\text { The Minister and the Minister of Technology stipulate that large } \\
\text { companies should enter into partnerships with micro, small and } \\
\text { medium-sized enterprises through innovation and development of } \\
\text { export-oriented products, employment, the use of suitable and } \\
\text { environmentally friendly technologies, and the provision of } \\
\text { incentives for education and training. }\end{array}$ \\
\hline Article 26 & $\begin{array}{l}\text { The partnership is implemented with the following } \\
\text { pattern: a. nucleus-plasma; b. subcontract; c. franchise; } \\
\text { d. general trading; e. distribution and agency; f. supply } \\
\text { chain; and g. other forms of partnership. }\end{array}$ & $\begin{array}{l}\text { The partnership is implemented with the following pattern: a. } \\
\text { nucleus-plasma; b. subcontract; c. franchise; d. general trading; e. } \\
\text { distribution and agency; f. other forms of partnership, such as } \\
\text { profit sharing, operational cooperation, joint ventures, and } \\
\text { outsourcing. }\end{array}$ \\
\hline Article 30 & $\begin{array}{l}\text { The implementation of the partnership with the general } \\
\text { trade model according to Article } 26 \text { letter d can take the } \\
\text { form of marketing cooperation or the provision of } \\
\text { business locations for micro, small and medium-sized } \\
\text { enterprises by large companies is open. } \\
\text { The needs for goods and services required by Large } \\
\text { Enterprises will be satisfied by prioritizing the } \\
\text { procurement of the products of Small Businesses or } \\
\text { Micro Enterprises as long as they meet the quality } \\
\text { standards of goods and services required. }\end{array}$ & $\begin{array}{l}\text { The implementation of the partnership referred to in Article } 26 \\
\text { letter d can be carried out in the form of business cooperation, } \\
\text { providing locations, or receiving supplies from Micro, Small, and } \\
\text { Medium Enterprises by Large Businesses. } \\
\text { Large Enterprises must prioritize the procurement of products } \\
\text { from Small Businesses or Micro Enterprises so long as the quality } \\
\text { of the products meets the standards required. } \\
\text { A payment system arrangement is made without harming either } \\
\text { party. }\end{array}$ \\
\hline
\end{tabular}




\begin{tabular}{|c|c|c|}
\hline & $\begin{array}{l}\text { The parties involved in making the payment system } \\
\text { arrangements are not harmed. }\end{array}$ & \\
\hline Article $32 \mathrm{~A}$ & $\begin{array}{l}\text { In the implementation of the partnership with the } \\
\text { supply chain pattern as referred to in Article } 26 \text { letter } \mathrm{f} \text {, } \\
\text { it can be carried out through the activities of Micro and } \\
\text { Small Enterprises by Medium and Large Enterprises at } \\
\text { least including a. the management of product transfers } \\
\text { carried out by the company with the raw material } \\
\text { provider; b. distribution of products from companies to } \\
\text { consumers; and/or c. management of the availability of } \\
\text { raw materials, supply of raw materials, and the } \\
\text { fabrication process. }\end{array}$ & There is not any \\
\hline $\begin{array}{ll}\text { Explanation } \\
\text { of } & \text { Article } \\
35 & \end{array}$ & $\begin{array}{l}\text { Paragraph (1) What is meant by "owning" is a legal } \\
\text { transfer of ownership of a business entity/company } \\
\text { and/or assets or assets owned by a Micro, Small, and/or } \\
\text { Medium Enterprise by a Large Business as its business } \\
\text { partner in the implementation of a partnership } \\
\text { relationship. } \\
\text { Paragraph (2) What is meant by "control" is the transfer } \\
\text { of juridical control over the business activities carried } \\
\text { out and/or assets or assets owned by Micro, Small, } \\
\text { and/or Medium Enterprises by Large Businesses as } \\
\text { business partners in the implementation of partnership } \\
\text { relations. }\end{array}$ & There is not any \\
\hline
\end{tabular}

Based on the table above, we can see that there are at least 8 (eight) provisions of the article in Law Number 20 of 2008 concerning Micro, Small, and Medium Enterprises that have changed. Thus, Law Number 23 of 2014 concerning Regional Government and Law Number 20 of 2008 in conjunction with Law Number 11 of 2020 are the basis for the authority of local governments in developing MSMEs.

The Job Creation Law helps MSME actors in developing their business. The change through the Job Creation Law attracts investment and helps the people's economy. The role of the Regional Government in this regard is also very necessary in overcoming the demands of economic globalization during increasingly competitive competition. Local governments in responding to changes and the direction of the legal policy of the Job Creation Law on the development of MSMEs, need to carry out strategies to achieve the same goals.

Local governments need to design strategies that can be carried out in implementing the provisions contained in the Job Creation Law. Government regulations as derivative rules of the Job Creation Law related to MSMEs have also been issued, namely Government Regulation Number 7 of 2021 concerning Ease, Protection, and Empowerment of Cooperatives and Micro, Small, and Medium Enterprises.

There are so many new legal policy directions in PP Number 7 of 2021 concerning the Ease, Protection, and Empowerment of Cooperatives and MSMEs. Based on Article 2 paragraph (1), the Central and Regional Governments provide convenience, protection, and empowerment for Cooperatives and MSMEs. Ease, protection, and empowerment for Cooperatives and
MSMEs is carried out through fostering and providing facilities. The following will describe the legal policies contained in PP No. 7 of 2021 concerning the Development of MSMEs.

First, the convenience of Micro and Small Businesses. This policy for the convenience of Micro and Small Businesses is carried out through:

a) Criteria for Micro, Small, and Medium Enterprises: Micro, Small, and Medium Enterprises are grouped based on the criteria for working capital or annual sales results. Used for the establishment or registration of business activities.

b) Risk-Based Business Licensing: Business Licensing for Micro, Small, and Medium Enterprises is granted based on the level of business activity risk in the form of business registration number, standard certificate, and/or permit. The Regional Government provides guidance and registration for Micro and Small Businesses to facilitate Business Licensing. The Regional Government also assists Micro and Small Businesses that have obtained a business registration number.

c) Single Licensing and Facilitation of Standard and/or Permit Certification: The Regional Government guides the fulfillment of single permits, standard certificates, and/or permits for Micro and Small Businesses.

\section{d) Business licensing information}

Second, Protection of Micro and Small Businesses. This business protection policy is carried out through:

a) Provision of Legal Aid and Assistance Services for Micro and Small Businesses: Legal assistance and 
assistance services include: a. legal counseling; b. legal consultation; c. mediation; preparation of legal documents; and/or d. assistance outside the court.

b) Recovery of Micro and Small Enterprises: The Regional Government seeks to restore Micro and Small Enterprises, including a. credit restructuring; b. business reconstruction; c. capital assistance; and/or d. other forms of assistance. This is to maintain the competitiveness of Micro and Small Business products in the domestic market.

Third, Empowering Micro, Small, and Medium Enterprises. This business empowerment policy is carried out through:

a) Single Database of Micro, Small, and Medium Enterprises.

b) Provision of Places for Promotion and Development of Micro and Small Businesses on Public Infrastructure: Provision of places for promotion and development of Micro and Small Businesses of at least $30 \%$ (thirty percent) of the total commercial area land area, shopping area, and/or strategic promotion places on public infrastructure. Local governments can also give appreciation in the form of incentives to business entities that provide a place for promotion and development of Micro and Small Enterprises following the allocation.

c) Integrated Management of Micro and Small Businesses: This is implemented in synergy by the Central Government, Regional Government, and related stakeholders through cluster structuring.

d) Facilitation of Intellectual Property Rights.

e) Credit Guarantee Program: Micro and Small Business Activities can be used as collateral for program credit. Program credit guarantees can be in the form of a. work order; b. invoice; c. letter of order (purchase order); d. intellectual property rights; e. factoring; f. chip/bar code (Chip/barcode) proof of ownership of movable objects; and/or g. employment contract.

f)Government procurement of goods/services: The Regional Government encourages regionallyowned enterprises to prioritize the use of the products of Micro, Small and Cooperative Enterprises in the procurement of goods/services.

g) Recording and Bookkeeping of the Financial Report Application System: The Regional Government facilitates training and assistance in the use of the financial bookkeeping/recording application system for Micro and Small Businesses.

h) Business Allocation for Micro and Small Businesses: and

i)Terminal Maintenance: Maintenance of the main facilities and supporting facilities at the terminal must cooperate with Micro and Small Businesses.
Fourth, Business Development. The development of Micro, Small, and Medium Enterprises is carried out through: a.) data collection and identification of potentials and problems faced by Micro, Small, and Medium Enterprises; b.) preparation of coaching and development programs according to the potential and problems encountered; c.) implementation of coaching and development programs; and d.) monitoring and controlling program implementation.

Fifth, Coordination and Control of Ease of Protection, and Empowerment of Micro, Small, and Medium Enterprises. In the coordination and control process stage, it is carried out by compiling and integrating, implementing, as well as monitoring and evaluating:

- laws and regulations and policies on climate growth and business development stipulated by the Central Government and Regional Governments;

- climate growth and business development programs organized by the Central Government and Regional Governments, the business world, and the community.

Meanwhile, Government Regulation Number 7 of 2021 also contains provisions in terms of partnerships; facilities, and incentives; providing financing for micro and small businesses; and maintenance of incubation.

Local governments have a role and authority in efforts to develop micro, small, and medium-sized enterprises. One of the main pillars of the national economy must obtain the main support, protection, and development as widely as possible since it aligns with the people's economic business group. Therefore, the local government must play a role in making it happen.

Since the regulation has changed since the issuance of the Job Creation Law, local governments need to accommodate legal developments and the needs of the community. Especially in a pandemic situation like today, the choice and speed of implementing policies to overcome the economic impacts that occur in society are very important. The consistency and political will of the local government in establishing legal regulations and regulations are considered very necessary.

Legal Framework that can be done by local governments is to form Regional Legal Products needed in the development of MSMEs. Based on the description in the previous discussion, the establishment of a Regional Regulation on the Ease, Protection, and Empowerment of Micro, Small, and Medium Enterprises is the right policy choice as a form of responsibility for local governments in developing MSMEs.

Regional regulations as one of the regional legal products play an important role and function in the administration of regional government. Article 18 paragraph (6) of the 1945 Constitution even stipulates 
that "Regional governments have the right to stipulate regional regulations and other regulations to carry out autonomy and assistance tasks." The regional government's attribution authority outlined in this provision becomes the constitutional basis for regional governments to form regional regulations.

Regional regulations as a form of regional legal product, are a formal legal form in the administration of regional government. The establishment of Regional Regulations in the context of administering regional government affairs, explicitly in the provisions of Article 17 paragraph (1) of Law Number 23 of 2014 also stipulates that "Regions have the right to determine Regional policies to carry out Government Affairs under the authority of the Regions."

The formation of local regulations in the development of MSMEs plays an important role in achieving legal objectives. This is because the local regulations are also attached to the legal functions contained therein. Bagir Manan has internal and external functions contained in statutory regulation, namely [15]:

a) Stability Function: Legislative regulations that function in the field of order and security rule that primarily aim to ensure the stability of society.

b) Change Function: Legislation is created or formed as an effort to encourage changes in society and government officials. This is following the teachings put forward by Rouscoe Pound regarding the law as social engineering, thus legislation is expected to be a means of reform.

c) Convenience Function: Legislation is expected to contain things that can provide convenience for the community and government officials.

d) Legal Assurance Function: The function of legal certainty or legal certainty is important in-laws and regulations regarding legal action and law enforcement, therefore laws and regulations are expected to provide legal certainty for the community and government officials.

In addition, the law as a system as stated by Lawrence M. Friedman, that law consists of components of structure, substance, and culture [16].

- The institutional component is the system created by the legal system with various functions and responsibilities to support the system. This component allows lawyers to see how the legal system provides services for the cultivation of legal materials regularly.

- The major component is the output of the legal system and is used by both parties in the regulation and the regulated system.

- The cultural component consists of the beliefs, values, and practices of the law that can have a significant impact on the workings of the law.
This legal culture provides citizens with a bridge that connects legal systems with the behaviors of citizens.

The Regional Regulation on the Ease, Protection, and Empowerment of Micro, Small, and Medium Enterprises is a legal substance that exists in the form of regulation. Mertokusumo stated that any legal relationship created by law has two components, rights, and obligations. On the other hand, there are no rights without obligations. Therefore, the implication is the birth of rights and obligations [17]. This is also reflected in the formation of Regional Regulations on the Ease, Protection, and Empowerment of Micro, Small, and Medium Enterprises as a legal framework for developing MSMEs by local governments. The existence of community rights is nothing but the government's obligation.

The development of MSMEs is very important in driving the national economy, considering that MSMEs' business activities cover almost all business fields [18]. The establishment of a Regional Regulation on the Ease, Protection, and Empowerment of Micro, Small, and Medium Enterprises as a legal framework will later become the direction of regional legal policy in developing MSMEs in accelerating economic recovery.

\section{CONCLUSIONS}

Based on the description that has been explained above, it can be concluded that the development of MSMEs is the authority and responsibility of the Regional Government, as a concurrent local government affair in mandatory government affairs that are not related to Basic Services. The enactment of Law Number 11 of 2020 concerning Job Creation and Government Regulation Number 7 of 2021 concerning Ease, Protection, and Empowerment of Cooperatives and Micro, Small, and Medium Enterprises has changed the direction of legal policy in the development of MSMEs. Local governments in this case have responsibilities and obligations in responding to the demands of these changes to overcome problems in the development of MSMEs. The strategy that can be carried out by the Regional Government is to form a Regional Regulation on the Ease, Protection, and Empowerment of Micro, Small, and Medium Enterprises as a form of the legal framework for developing MSMEs. The legal policy in this regional regulation at least regulates the convenience of Micro and Small Businesses; Protection of Micro and Small Businesses; Empowerment of Micro, Small, and Medium Enterprises; Business development; Coordination and Control of Ease of Protection, and Empowerment of Micro, Small, and Medium Enterprises; partnership; facilities and incentives; providing financing for micro and small businesses; and maintenance of incubation. 


\section{ACKNOWLEDGMENT}

This research can be done well thanks to the funds provided by the government of the Republic of Indonesia through a base research grant scheme at the University of Lampung. We would like to thank you in advance for your generous financial support of this research.

\section{REFERENCES}

[1] General Section Explanation of Law Number 11 of 2020

[2] General Section Explanation of Law Number 20 of 2008 concerning Micro, Small and Medium Enterprises

[3] https://www.indonesia.go.id/narasi/indonesia-dalamangka/ekonomi/klaster-umkm-kemudahan-bagi-yang-lemahdan-kecil

[4] Peter Mahmud Marzuki, Penelitian Hukum. (Jakarta: Prenada Media, 2005).

[5] Widyaningrum, N. (2003). Pola-pola eksploitasi terhadap Usaha Kecil. Yayasan Obor Indonesia..

[6] Laurensius Arliman S, Perlindungan Hukum UMKM dari Eksploitasi Ekonomi dalam Rangka Peningkatan Kesejahteraan Masyarakat, Jurnal Rechtsvinding Media Pembinaan Hukum Nasional, Volume 6, Nomor 3, Desember 2017.

[7] Mubyarto, 2001. Pemulihan Ekonomi Nasional Menuju Demokrasi Ekonomi, Jurnal Ekonomi dan Bisnis Indonesia Vol.16, No.1, 2001.

[8] Zulkarnain, Kewirausahaan (Strategi Pemberdayaan Usaha Kecil Menengah Dan Penduduk Miskin), (Yogyakarta: Adicita Karya Nusa, 2006), p. 98
[9] A.Z. Fachri Yasin, dkk, Petani, Usaha Kecil Dan Koperasi Berwawasan Ekonomi Kerakyatan, (Pekanbaru: Unri Press, 2002), pp.2-3

[10] Soeharto Prawiro Kusumo, Ekonomi Rakyat: Konsep Kebijakan dan Strategi, (Yogyakarta: BPFE), p. 4

[11] Mubyarto in Indra Ismawan, Sukses di Era Ekonomi Liberal bagi Koperasi dan Perusahaan Kecil Menengah, (PT. Grasindo: Jakarta, 2001), p.97

[12] Rozali Abdullah, Pelaksanaan Otonomi Luas dengan Pemilihan Kepala Daerah secara Langsung, (Jakarta: PT Raja Grafindo Persada, 2005), p. 12.

[13] Hoessein, B., Prospek Resolusi Kebijakan dan Implementasi Otonomi Daerah dari Sudut Pandang Hukum Tata Negara, disampaikan pada Seminar dan Lokakarya Nasional Strategi Resolusi Kebijakan dan Implementasi Otonomi Daerah Dalam Kerangka Good Governance, Lembaga Administrasi Negara, Jakarta, 2001.

[14] Kementerian Sekretariat Negara. "Undang-Undang Republik Indonesia Tahun 2020 Tentang Cipta Kerja

[15] Bagir Manan, Dasar-dasar Konstitusional Peraturan perundang-undangan Nasional, Padang; Fakultas Hukum Universitas Andalas, 1994., p.13

[16] Lawrence M. Friedman. 1986. The Legal System: A Social Science Perspective. Newyork: Russel Sage Foundation. Dalam Esmi Warassih. 2011. Pranata Hukum Sebuah Telaah Sosiologis. Semarang, Badan Penerbitan Universitas Diponegoro. p.27

[17] Sudikno Mertokusumo. 1986. Mengenal Hukum, Suatu Pengantar. Yogyakarta: Liberti. p.41

[18] Feni Dwi Anggraeni, et all, Pengembangan Usaha Mikro, Kecil, Dan Menengah (UMKM) Melalui Fasilitasi Pihak Eksternal Dan Potensi Internal. Jurnal Administrasi Publik (JAP), Vol. 1, No. 6, Hal. 1286-1295 